\title{
Assessment of the Effect of Fungal Parasites and Callosobruchus maculatus Fab. on the Physiological and Biochemical Parameters of Cowpea (Vigna unguiculata (L.) Walp.) Seeds in Côte d'Ivoire
}

\section{Ouattara Généfol'1, Johnson Félicia ${ }^{2}$, Tuo Seydou ${ }^{1}$, Soro Sibirina ${ }^{3}$, Essis Brice Sidoine ${ }^{4}$, Doumbouya Mohamed 5 , Bomisso Edson Lezin'1, Koné Daouda1}

\begin{abstract}
${ }^{1}$ Laboratoire de Physiologie Végétale, UFR Biosciences, Université Félix Houphouët-Boigny de Cocody, 22 BP 582 Abidjan, Côte d'Ivoire

${ }^{2}$ Laboratoire de Zoologie et Biologie Animale, UFR Biosciences, Université Félix Houphouët-Boigny de Cocody, 22 BP 582 Abidjan, Côte d'Ivoire

${ }^{3}$ Laboratoire de Physiologie Végétale, UFR Agroforesterie, Université Jean Lorougnon Guédé de Daloa, BP 150 Daloa, Côte d'Ivoire

${ }^{4}$ Centre National de Recherche Agronomique (CNRA), Station de recherche de Bouaké, 01 BP 633 Bouaké 01, Côte d'Ivoire

${ }^{5}$ UFR des Sciences Biologiques, Unviversité Péléforo Gon Coulibaly de Korhogo, BP 1328 Korhogo, Côte d'Ivoire

Abstract: Cowpea (Vigna unguiculata (L.) Walp.), is a legiminous plant grown in the tropical regions of Africa. It is used in food and feed because of its high protein content. However, its storage and preservation are affected by numerous abiotic and biotic constraints including fungi and insects. This work was initiated with the aim of sanitary analyzing, physiological and biochemical state of Cowpea seeds, in order to seek and remove the constraints related to their viability. Purity, contamination and germination tests were carried out. Different culture media (PDA and blotting paper) were used for the tests. Seed viability by area of attack by Callosobruchus maculatus, main pest of Cowpea stocks, was also tested. The biochemical compounds of the seeds were assayed. The results indicated that the purity of the Cowpea seeds collected from the different markets of Abidjan was satisfactory overall, with a rate of more than $95 \%$ recorded. In contrast, the seeds were susceptible to attacks by fungal microorganisms and insects. Thus, two fungi were isolated and purified. Macrophomina phaseoli species roved to be harmful to Cowpea seeds stored. These fungi prevent seed germination and degrade their biochemical compounds. Also, perforation of seeds at the hilum by Callosobruchus maculatus also prevents germination. Macrophomina phaseoli and Callosobruchus maculatus are real constraints of Cowpea during storage.
\end{abstract}

Keywords: Cowpea, Germination, Macrophomina phaseoli, Callosobruchus maculatus, Côte d'Ivoire

\section{Introduction}

Cowpea (Vigna unguiculata (L.) Walp.), originating from South-East Africa, is one of the major leguminous grown and consumed in the tropics and subtropics. Its high protein content $(25 \%)$ is used for the nutritional balance of people in these regions whose basic diet is made up of cereals, roots and tubers, not containing enough protein elements (Djilé et al., 2016). Indeed, this nutrient-rich food, with a protein content of up to $25 \%$ and carbohydrates of 60 to $65 \%$, represents one of the best and least expensive solutions that can significantly contribute to global food security (Ait, 2017). Cowpea is a plant traditionally grown most often in combination with other food crops such as corn, millet, sorghum (N'Gbesso et al., 2013, Toudou et al., 2016). The world's annual cultivated area is more than 11.8 million hectares, including 10.7 million hectares in 
Assessment of the Effect of Fungal Parasites and Callosobruchus maculatus Fab. on the Physiological and Biochemical Parameters of Cowpea (Vigna unguiculata (L.) Walp.) Seeds in Côte d'Ivoire

West Africa, the largest area of Cowpea production and consumption in the world (Ouali-N'Goran et al., 2014). Young shoots, fresh pods and leaves are eaten as leafy vegetables (N'Gbesso et al., 2013, Gbaguidi et al., 2015). As for the seeds, they are used mainly as pulses.

Depending on the color and the nature of the seed coat, several varieties of this plant are distinguished from one another. These include: brown and smooth seeded, white and smooth seeded, white and rough seeded and bicolored and rough seeded varieties (Lalsaga et al., 2017).

In Côte d'Ivoire, dry Cowpea yield was estimated at 39165 tons in 2016 (FAO, 2017). Its cultivation area extends mainly in the Sudanese zone, but goes down to the vicinity of Bouaké, in the center of the country. Indeed, Cowpea yield and preservation are unfortunately faced with several socio-economic, abiotic and biotic constraints, including the attack of seeds by insects, nematodes, viruses, bacteria and fungi on-farm as well as during storage (Sérémé, 1999, Guèye et al., 2011). Thus, in Côte d'Ivoire, such difficulties have led farmers to lose interest in Cowpea cultivation. In recent years, climate change caused by deforestation, livestock product shortages and changes in eating habits have led to a renewed interest in this crop in order to correct dietary deficiencies and fill the protein deficit in vulnerable populations.

This present study was initiated in order to make the sanitary and physiological analysis of Cowpea seeds, in order to seek and remove the constraints related to their viability. It consist in identifying and studying the influence of fungal parasites and insect attacks on Cowpea seeds, particularly smooth white seeds.

In order to achieve this goal, several tests were carried out. These included: purity, contamination and germination tests depending on the areas of attack of the seed by Callosobruchus maculatus, main insect pest of Cowpea stocks. The biochemical compounds of the seeds were also quantified in order to assess the effect of the contaminations on them.

\section{MATERIAL AND METHODS \\ 1. Study site}

The experiments were carried out at the Laboratory of Plant Physiology of the University Felix Houphouet-Boigny in Abidjan, Côte d'Ivoire.

The city of Abidjan is located between $5^{\circ} 17^{\prime}$ and $5^{\circ} 31^{\prime}$ west longitude and between $3^{\circ} 45^{\prime}$ and $4^{\circ} 31^{\prime}$ north latitude. The climate of Abidjan is Attiean. It is characterized by four seasons like in the center of the country (Akédrin et al., 2011). The vegetation is made up of dense rainforest and rainfall is high (1400 to $2400 \mathrm{~mm} /$ year). The area is characterized by two rainy seasons (April to July and October to November) spaced by two dry seasons (December to March and August to September). The temperature is less variable during the year (between 25 and $30^{\circ} \mathrm{C}$ ) and the relative humidity is very high; greater than $80 \%$, (Djè et al., 2005).

\section{Plant and animal material}

The plant material used in this study consisted of Cowpea seeds (Smooth white seeds variety) collected from different markets of Abidjan. The animal biological material was represented by Callosobruchus maculatus (Coleoptera: Bruchidae), used for infesting the selected seeds.

\section{Methods}

\subsection{Sampling}

The Cowpea seeds used for the different tests were collected from 6 municipalities of the city of Abidjan at a rate two markets per municipality, that is, 12 markets overall (Table 1). A sample of $500 \mathrm{~g}$ of Cowpea was collected from each market. The samples were taken at three levels of the stocks (top, middle and bottom). Subsequently, a composite sample was formed by mixing the seeds of those three sampling levels. The selection of those markets was based on the fact that they were supply areas for the other markets of the city of Abidjan. Cowpea seed stocks in those markets come from 3 countries (Table 1). 
Assessment of the Effect of Fungal Parasites and Callosobruchus maculatus Fab. on the Physiological and Biochemical Parameters of Cowpea (Vigna unguiculata (L.) Walp.) Seeds in Côte d'Ivoire

Table 1. Origin of the different samples of Cowpea seed collected from Abidjan markets

\begin{tabular}{lll}
\hline Municipalities & Markets & Origin \\
\hline \multirow{3}{*}{ Cocody } & Angré Market & Burkina Faso \\
\cline { 2 - 3 } Koumassi & Saint-Jean Market & Burkina Faso \\
\hline \multirow{3}{*}{ Abobo } & Djè Konan Market & Niger \\
\cline { 2 - 3 } Yopougon & Koumassi Big Market & Niger \\
\hline \multirow{3}{*}{ Adjamé } & Abobo Big Market & Mali \\
\hline \multirow{3}{*}{ Treichville } & Cité Abobo Market & Mali \\
\hline
\end{tabular}

\subsection{Morphological characterization of Cowpea seeds}

3.2.1. Seed purity analysis

The purity analysis consisted of selecting three $100 \mathrm{~g}$ samples per lot and ridding them of all impurities. Broken seeds, seeds of other plant species, nonmature seeds and insect debris were removed using forceps and spatula (ISTA, 1999 and 2005). The mass of the different samples made was determined using a SARTORIUS precision balance $\left(10^{-3} \mathrm{~g}\right)$. Then, the rates of pure, intact, damaged and apparently contaminated seeds and those of the residues were calculated respectively according to the following formulas:

Purity $(\%)=$ (pure seeds weight $/$ total weight of the sample) x 100

Intact seeds $(\%)=($ intact seeds weight/total weight of the sample) $\mathrm{x} 100$

Damaged seeds $(\%)=($ damaged seeds weight $/$ total weight of the sample) $\times 100$

Contaminated seeds $(\%)=$ (contaminated seeds weight / total weight of the sample) x 100

Residue $(\%)=($ weight of residues/total weight of the sample) x 100

\subsubsection{Determination of the weight of 1000 seeds}

The techniques used to determine the weight of 1000 seeds were those proposed by Paul (1972), Bonner (1974) and the ISTA (1976). They have been modified for the occasion. Three samples of 1000 intact seeds were made at each lot. Then, the weight of each sample of 1000 intact seeds was determined using a SARTORIUS precision balance $\left(10^{-3} \mathrm{~g}\right)$. For samples of less than 1000 intact seeds, 8 samples of 100 intact seeds were made and weighed with the same balance. Then the average weight of 100 intact seeds was determined and reduced to the weight of 1000 intact seeds.
3.3. Assessment of the influence of fungi on the biochemical compounds of Cowpea seeds

3.3.1. Preparation of samples for biochemical analyses

The samples of the different lots stemming from the purity analysis (apparently healthy seeds and contaminated seeds) were washed separately three times with drinking water and rinsed with distilled water. They were then oven-dried at $50{ }^{\circ} \mathrm{C}$ for 48 hours before being crushed using an IKA stainless steel grinder. The flours obtained were sieved with a 0.5 millimeter-diameter sieve. The residues obtained were crushed again until exhaustion. Fine flours were kept in sterile polystyrene pots and stored in a refrigerator at $4{ }^{\circ} \mathrm{C}$ for the different biochemical analyses.

\subsubsection{Biochemical analysis methods}

On the different Cowpea samples, biochemical parameters such as protein content, fat content (lipids and fatty acids) and total carbohydrate content were determined. The Kjeldahl method (AOAC, 2005) was used for the protein assay. About $0.1 \mathrm{~g}$ of Cowpea seed flour was used to determine the crude protein content from the total nitrogen assay expressed in percentage (\%). The protein content was obtained by multiplying the total nitrogen content by conversion factor 6.25. The Soxhlet method (ISO, 1998) has helped extract the fat from seed samples using an extraction solvent (hexane) thanks to the Soxhlet apparatus. The fat contents of the seeds were expressed in percentage $(\%)$.

The total carbohydrate rate was determined according to the Bertrand and Thomas formula (1910):

Total carbohydrate $(\%)=100-(\%$ moisture $+\%$ protein $+\%$ fat $+\%$ ash) 
Assessment of the Effect of Fungal Parasites and Callosobruchus maculatus Fab. on the Physiological and Biochemical Parameters of Cowpea (Vigna unguiculata (L.) Walp.) Seeds in Côte d'Ivoire

4. Sanitary and physiological characterization of Cowpea seeds

4.1. Sanitary and physiological test of seeds in trays

4.1.1. Seed preparation and setting for germination

Three samples of 100 intact seeds were formed per lot. Three glass jars with a volume of $1 \mathrm{~L}$ each containing distilled water were used to soak the different seedlots for $3 \mathrm{~h}$. Blotting paper as substrate was used to cover the bottom of germination trays. Then, the bottom of each tray was delimited into three equal parts where the different seed samples were arranged (Figure 1). For each lot, the seeds soaked for $3 \mathrm{~h}$ were placed in three rows in the germination tray with a sterile fine forceps so as to prevent contamination (Figure 1). Then, the seeds were sprinkled with distilled water using a wash bottle. The tanks were then incubated in the culture room under a photoperiod of $12 \mathrm{~h}$ at a temperature of $25 \pm 2{ }^{\circ} \mathrm{C}$

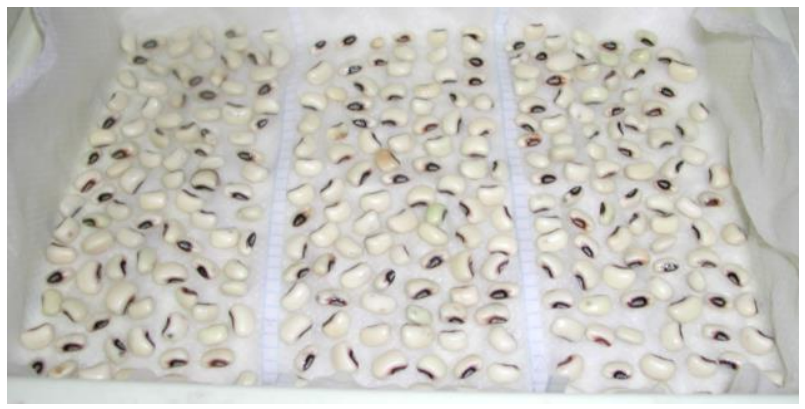

Figure 1: Setting for Cowpea seeds germination in trays

\subsubsection{Monitoring of germination and seed contamination}

The seeds set for germination were monitored daily so as to determine germination rate and contamination rate. Those that germinated were progressively removed from the trays after counting until there were no more germinated seeds after 3 days. The germination rates (TG) were calculated by the following formula:

TG $(\%)=$ (number of germinated seeds/total number of seeds set for germination in the lot) $\mathrm{x} 100$

The number of seeds contaminated by fungi was determined by counting. Then, the contamination rates (TC) were assessed by the following formula:

TC $(\%)=$ (number of seeds contaminated $/$ total number of seeds sown per lot) x 100
4.2. Sanitary and physiological test on glucoseenriched media or PDA media

\subsubsection{Preparation of the PDA media}

The culture media used was Potato Dextrose Agar (PDA). This media was prepared by adding $20 \mathrm{~g}$ of mashed potato to $20 \mathrm{~g}$ of glucose and $20 \mathrm{~g}$ of agar in an Erlenmeyer flask. The volume of the mixture was adjusted with distilled water at $1 \mathrm{~L}$. The mixture was autoclaved at $121{ }^{\circ} \mathrm{C}$ under a pressure of 1 bar for 30 minutes. The media was then cooled to a temperature of $45^{\circ} \mathrm{C}$. The preparation obtained received $350 \mu \mathrm{l}$ of lactic acid, $250 \mathrm{mg} / \mathrm{l}$ of ampicillin and $10 \mathrm{mg} / \mathrm{L}$ of rifampicin. The whole was homogenized through stirring and then distributed under the laminar flow hood in sterile $90 \mathrm{~mm}$-diameter Petri dishes at a rate of $20 \mathrm{ml}$ per dish.

\subsubsection{Seed preparation}

The seeds that were used in this test were the apparently healthy (intact) seeds and the apparently contaminated seeds from the purity test (Figure $2 \mathrm{~A}$ and B). Each type of seed was disinfected with a $4 \%$ hypochlorite solution.

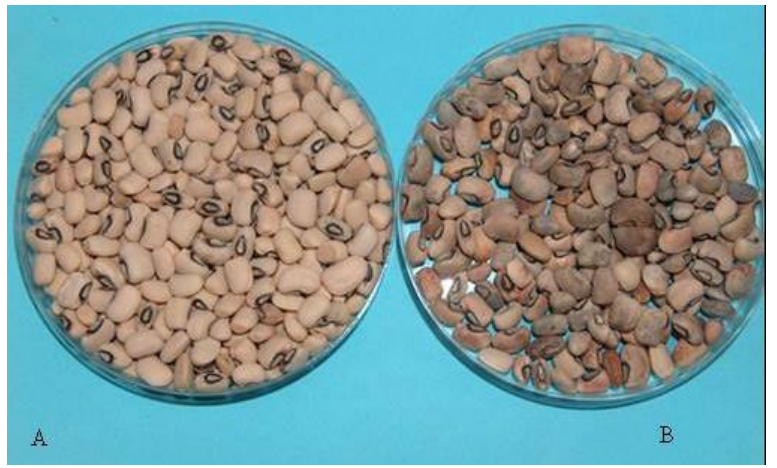

Figure 2. Apparently healthy (A) and apparently contaminated (B) Cowpea seeds used for sanitary and physiological tests on culture media

\subsubsection{Isolation, purification and identification of endogenous fungi associated with seeds}

The Petri dishes containing the previously prepared solidified PDA culture media were seeded under a laminar flow hood, and in the presence of a flame. The seeds were previously disinfected with sodium hypochlorite $(4 \%)$ for $2 \mathrm{~min}$ and rinsed with sterile distilled water, 3 times successively for $3 \mathrm{~min}$. The seeds thus prepared were set to dry on sterile blotting paper for 10 minutes. They were then distributed in the Petri dishes containing the PDA culture media at the rate of 5 seeds of each type per dish. The preparations were incubated under a $12 \mathrm{~h}$ photoperiod at a temperature of $25 \pm 2{ }^{\circ} \mathrm{C}$ for $72 \mathrm{~h}$. Purifications were made by transferring the fungus mycelium taken from colonies evolved on the growing front 
Assessment of the Effect of Fungal Parasites and Callosobruchus maculatus Fab. on the Physiological and Biochemical Parameters of Cowpea (Vigna unguiculata (L.) Walp.) Seeds in Côte d'Ivoire

into new Petri dishes containing the same culture media. This operation was repeated three times. The isolates were purified so as to obtain a culture for the identification of pathogens. Forty-eight hours after sporulation, the fungi were identified by macroscopic and microscopic observations. These observations mainly concerned the color and appearance of fungal thalli based on the Barnet and Barry compendium (1972). Also, the isolation rates of the different fungi were expressed as a percentage of the total number of seeds sown.

\subsubsection{Monitoring of contamination and seed germination}

Fungi-contaminated seeds (primary isolation) and germinated seeds on PDA culture media were counted daily during the three days of incubation, and contamination (TC) and germination (TG) rates were determined like before.

\subsection{Sanitary and physiological test on blotting paper \\ Under a laminar flow hood and near a flame, 20 Cowpea seeds disinfected with $4 \%$ sodium hypochlorite were spread evenly between two sterile blotting papers in five equal rows. The whole was sprinkled with sterile distilled water. After seeding on sterile blotting papers, the whole was put in culture room for observation. Thus, after 72 hours of incubation under a 12-hour photoperiod at a temperature of $25 \pm 2{ }^{\circ} \mathrm{C}$, the contaminated seeds, on the one hand, and germinated seeds, on the other hand, were counted so as to determine the rates of contamination and germination relative to the total number of seeds sown.}

\section{Search for seed surface fungi on PDA media}

A piece of sterile cotton swab was immersed in sterile distilled water contained in a jar and removed. This tip thus treated, was stung several times in a seed lot contained in a bag with a view to trapping the fungal spores located on the surface of the seeds. The tip, which was a spore trap, was deposited on PDA culture media at several different and wellspaced places. After this, the Petri dishes were sealed with adhesive film; then each deposit of the cotton swab tip was numbered on the underside of the Petri dish. The incubation lasted at least three days in the culture room under a 12-hour photoperiod at $25 \pm 2$ ${ }^{\circ} \mathrm{C}$. This was carried out for each lot. The method of purification of surface fungi was the same as that of fungi from the inside of seeds. After purification, a macroscopic and microscopic description of the pure strains was performed. It took into account the color, the appearance of the thalli and the presence or absence of spores.

\section{Assessment of the influence of water and biotic factors on Cowpea seed viability under shelter 6.1. Preparation of soil samples}

The soil used was sterilized twice in an autoclave at $121{ }^{\circ} \mathrm{C}$ under a pressure of 1 bar for 30 minutes at a 24-hour interval. At the end of this operation and after cooling the samples, the soil was distributed in 160 pots of $200 \mathrm{ml}$ where the different seeds were sown at a rate of one seed per pot. The experiments were conducted under a $2.6 \mathrm{~m}$-long; $2.2 \mathrm{~m}$-wide and $3.4 \mathrm{~m}$-high shelter. The shelter was covered with transparent polyethylene plastic with two openings on the parallel sides. The temperature and hygrometry ranged between 31.70 to $45.70{ }^{\circ} \mathrm{C}$ and 31 to $68 \%$, respectively.

\subsection{Seed conditioning}

Seed lots were conditioned with a view to testing the influence of water and biological factors on Cowpea seed viability. Thus, intact seeds (T1) and seeds soaked for $4 \mathrm{~h}$ (T2), $3 \mathrm{~h}$ (T3), $2 \mathrm{~h}$ (T4) and apparently contaminated seeds (T5) were tested. Another lot of $200 \mathrm{~g}$ of seeds, submitted to infestation for two months by Callosobruchus maculatus, the main pest of Cowpea stocks, was also used. The seeds perforated at the hilum (T6), opposite the hilum (T7) and on the lateral face (T8) were selected so as to test the impact of the insect's attacks on Cowpea seed viability.

\subsection{Experimental design}

The assessment of the influence of the different factors on seed viability under shelter was carried out on a space whose dimensions were $2.4 \mathrm{~m} \times 2.1 \mathrm{~m}$. The pots were arranged according to a Fisher design in five blocks with a randomization inside each block. Each elementary plot consisted of four pots, that is, four seeds (one seed per pot). Also, each elementary plot constituted a treatment. In total, there were 8 treatments as indicated in the seed conditioning (T1, T2, T3, T4, T5, T6, T7 and T8). The seeding was made at a depth of $2 \mathrm{~cm}$ in the different pots (Akédrin et al., 2011). Two watering sessions were performed each day (morning and evening). This test was repeated twice in time.

\subsection{Determinations of growth parameters of plants stemming from seeding under shelter 6.4.1. Seed germination rate}

Observations were made every day after seeding, for a total of 6 days. Germination rates (TG) were calculated for each treatment and for each day by the previous germination rate formula.

\subsubsection{Measurement of growth parameters}

Observations and measurements were made weekly after seeding over a four-week period. The growth parameters assessed included the number of leaves 
Assessment of the Effect of Fungal Parasites and Callosobruchus maculatus Fab. on the Physiological and Biochemical Parameters of Cowpea (Vigna unguiculata (L.) Walp.) Seeds in Côte d'Ivoire

generated, plant height growth and stem diameter. The number of leaves generated was counted on each seedling stemming from the different treatments during each observation. The average number of leaves generated was calculated per treatment. Seedling height was determined using a tape measure from cotyledonary scars to apical buds. The average stem length per treatment was determined. As for stem diameter, it was measured with a "Mitutoyo" hand caliper. These measurements were made just above the cotyledonary scars. The average diameter per treatment was subsequently calculated.

\section{Statistical analysis of the data}

The data collected during this study were subjected to an analysis of variance (ANOVA) using the STATISTICA version 7.1 software. This analysis has helped assess the effects of water and biotic factors (fungi and insect pests) on the sanitary and physiological parameters of seeds. Where there was a significant difference between the averages, the Newman-Keuls multiple comparison test at 5\% threshold was used to classify them into homogeneous groups.

\section{RESULTS}

\section{Morphological characteristics of Cowpea seeds 1.1. Purity of the samples}

The purity and residue rates recorded for the different samples recorded varied respectively from 95.10 to $100 \%$ and from 0 to $4.90 \%$. The Big market of Koumassi had the lowest seed purity rate, that is, 95.10\% and the market of Cocody Saint-Jean had the highest seed purity rate, that is, $100 \%$ (Table 2). The highest seed residue rate was obtained at the Big market of Koumassi with $4.90 \%$ of residues while that of the market of Cocody Saint-Jean was nil (0\%). Significant differences were observed at $5 \%$ threshold of the Newman-Keuls test for these two parameters.

\subsection{Rates of intact seeds and damaged seeds}

The analysis of variance showed that intact seed rates varied from 65.96 to $88.78 \%$ (Table 2). The highest intact seed rate was the one of Saint-Jean market $(88.78 \%)$ and the lowest intact seed rate was observed in the Big market of Koumassi at $65.96 \%$ (Table 2). Significant differences were observed at $5 \%$ threshold of the Newman-Keuls test. The rates of damaged seeds varied from 11.11 to $25.16 \%$. The lowest damaged seed rate was observed in the Big market of Abobo (11.11\%) and the highest rate was recorded in the Big market of Koumassi with 25.16\% of damaged seeds (Table 2). The differences observed were significant at $5 \%$ threshold of the Newman-Keuls test.

\subsection{Apparently contaminated seed rate}

Apparently contaminated seed rates ranged from 0 to $8.5 \%$. The apparently contaminated seed rate in "Saint Jean" market was nil while the one of the Big Market of Abobo was the highest, that is $8.5 \%$ (Table 2 ). The differences observed were significant at $5 \%$ threshold (Newman-Keuls test).

\subsection{Weight of 1000 intact seeds}

The weights of 1000 seeds ranged from 139.60 to $159.54 \mathrm{~g}$. The highest weight was recorded in the Gouro market in Adjamé at $159.54 \mathrm{~g}$, while the lowest weight was the one of the market of Yopougon camp militaire at $139.60 \mathrm{~g}$ (Table 2). The differences observed were significant at 5\% level (Newman and Keuls test).

\section{Influence of fungi on the biochemical compounds of seeds}

The carbohydrate content of healthy seeds $(79.70 \%)$ was significantly higher than that of contaminated seeds $(69.15 \%)$ (Table 3$)$.

Healthy seeds had the highest protein content at $22.09 \%$ and contaminated seeds had the lowest protein content at $19.25 \%$ (Table 3 ). The difference observed was significant at $5 \%$ threshold of the Newman-Keuls test.

Contaminated seeds had the highest fat content, that is, $4.30 \%$ while healthy seeds had the lowest one $(2.88 \%)$ (Table 3). The difference observed was significant at $5 \%$ threshold of the Newman-Keuls test.

\section{Sanitary and physiological characteristics of seeds}

3.1. Contamination and germination rate in trays Seed contamination rate in trays ranged from 0 to $13 \%$ (figure 3). The seed lot from the Angré market had the lowest or even nil contamination rate $(0 \%)$ while that of the Big Market of Abobo was the highest (13\%). The differences observed were significant $(\mathrm{p}<0.001)$ at $5 \%$ threshold of the Newman-Keuls test. As for seed germination rate in trays, it ranged from 57 to $91.33 \%$ with significant differences $(p<0.001)$ at $5 \%$ threshold of the Newman-Keuls test. The highest germination rate $(91.33 \%)$ was observed with the seeds from the Selmer market in Yopougon, while the lowest germination rate $(57 \%)$ was observed with the seeds from the Big market of Abobo (Figure 3).

\subsection{Contamination and germination rate on PDA media}

Based on macroscopic characteristics, two fungi were isolated and purified from seed samples provided by the different markets of Abidjan. These included a white fungus and a black fungus. 
Assessment of the Effect of Fungal Parasites and Callosobruchus maculatus Fab. on the Physiological and Biochemical Parameters of Cowpea (Vigna unguiculata (L.) Walp.) Seeds in Côte d'Ivoire

Regarding apparently contaminated seeds, the black phenotype fungus had a frequency of occurrence (76\%) significantly higher than that of healthy seeds, that is, $4 \%$ (Table 4). For the apparently contaminated seeds, the frequency of occurrence of the white phenotype fungus was relatively high $(5.33 \%)$ compared to that of the apparently healthy seeds which was $2.66 \%$ (Table 4 ). The difference observed was not significant at $5 \%$ threshold of the Newman-Keuls test.

Concerning the apparently contaminated seeds, the black phenotype fungus had a contamination rate $(76 \%)$ significantly higher than that of the white phenotype fungus which was $5.33 \%$ (Table 4). In apparently healthy seeds, the black phenotype fungus had the highest frequency of occurrence $(4 \%)$ while the white phenotype fungus occurred less at $2.66 \%$ (Table 4). The difference observed was not significant at $5 \%$ threshold of the Newman-Keuls test.
The germination rate of healthy seeds was $100 \%$ while that of contaminated seeds was very low, that is, $9.33 \%$ (Table 4). The difference observed was significant at $5 \%$ threshold of the Newman-Keuls test.

\subsection{Contamination and germination rate on blotting paper}

The results obtained showed that the sanitary and physiological condition of the seeds on blotting paper varied according to the onset of the seeds (Table 5). The test revealed that there were $66.67 \%$ noncontaminated germinated seeds for type 1 (apparently healthy seeds) against $0 \%$ non-contaminated germinated seeds for type 2 (apparently contaminated seeds); $4.97 \%$ non-contaminated non-germinated seeds for type 1 against 5\% for type 2; $19.17 \%$ nongerminated contaminated seeds for type 1 against $95 \%$ for type 2 and $10 \%$ contaminated germinated seed for type 1 seeds $0 \%$ for type 2 (Table 5).

Table 2. Morphological Characteristics of seeds

\begin{tabular}{|c|c|c|c|c|c|c|c|}
\hline \multirow{2}{*}{$\begin{array}{l}\text { Origin of } \\
\text { seeds }\end{array}$} & \multicolumn{4}{|c|}{ Purity of $100 \mathrm{~g}$ samples } & \multicolumn{2}{|c|}{ Appearance of $100 \mathrm{~g}$ of seeds } & \multirow[b]{2}{*}{$\begin{array}{l}\text { Weight of } 1000 \text { intact } \\
\text { seeds }(\mathrm{g})\end{array}$} \\
\hline & Pure seed rate (\%) & $\begin{array}{l}\text { Residue rate } \\
(\%)\end{array}$ & $\begin{array}{l}\text { Intact seed rate } \\
(\%)\end{array}$ & $\begin{array}{l}\text { Damaged seed rate } \\
(\%)\end{array}$ & $\begin{array}{l}\text { Contaminated } \\
\text { seed rate }(\%)\end{array}$ & $\begin{array}{l}\text { Residue rate } \\
(\%)\end{array}$ & \\
\hline MSJ & $100.00 \pm 0.00 \mathbf{a}$ & $0.00 \pm 0.00 \mathrm{~d}$ & $88.08 \pm 4.25 \mathbf{a}$ & $11.92 \pm 1.55 \mathbf{c}$ & $0.00 \pm 0.00 \mathbf{c}$ & $0.00 \pm 0.00 \mathrm{~d}$ & $140.33 \pm 2.50 \mathrm{c}$ \\
\hline MAN & $99.80 \pm 0.05 \mathbf{a}$ & $0.20 \pm 0.02 \mathbf{c}$ & $76.75 \pm 2.88 \mathbf{a b}$ & $23.25 \pm 2.70 \mathbf{a b}$ & $0.00 \pm 0.00 \mathbf{c}$ & $0.00 \pm 0.00 \mathrm{~d}$ & $151.00 \pm 3.75 \mathbf{b}$ \\
\hline MR21 & $99.60 \pm 0.15 \mathbf{a}$ & $0.40 \pm 0.04 \mathbf{c}$ & $81.17 \pm 3.68 \mathbf{a}$ & $18.83 \pm 1.40 \mathbf{b}$ & $3.80 \pm 0.75 \mathbf{b c}$ & $0.50 \pm 0.02 \mathrm{~d}$ & $156.73 \pm 2.66 \mathbf{a b}$ \\
\hline NMT & $99.20 \pm 0.45 \mathbf{a}$ & $0.80 \pm 0.09 \mathbf{c}$ & $84.25 \pm 1.75 \mathbf{a}$ & $15.75 \pm 01.60 \mathbf{c}$ & $6.10 \pm 0.15 \mathbf{a b}$ & $0.75 \pm 0.06 \mathrm{~d}$ & $154.80 \pm 3.72 \mathbf{b}$ \\
\hline MDK & $99.40 \pm 0.95 \mathbf{a}$ & $0.60 \pm 0.08 \mathbf{c}$ & $77.95 \pm 4.50 \mathbf{a b}$ & $22.05 \pm 3.20 \mathbf{a b}$ & $4.20 \pm 0.90 \mathbf{b}$ & $1.50 \pm 0.05 \mathbf{c}$ & $154.10 \pm 2.05 \mathbf{b}$ \\
\hline GMA & $98.50 \pm 0.70 \mathbf{a b}$ & $1.50 \pm 0.05 \mathbf{b}$ & $85.25 \pm 3.20 \mathrm{a}$ & $14.75 \pm 2.70 \mathbf{c}$ & $8.30 \pm 0.75 \mathbf{a}$ & $1.60 \pm 0.80 \mathrm{c}$ & $147.25 \pm 4.78 \mathbf{c}$ \\
\hline MFA & $96.80 \pm 0.70 \mathbf{b}$ & $3.20 \pm 0.25 \mathbf{a b}$ & $76.20 \pm 2.66 \mathbf{a b}$ & $23.80 \pm 2.80 \mathbf{a b}$ & $3.75 \pm 0.80 \mathbf{b c}$ & $1.80 \pm 0.70 \mathbf{c}$ & $152.10 \pm 3.80 \mathbf{b}$ \\
\hline MGA & $96.65 \pm 1.35 \mathbf{b}$ & $3.35 \pm 0.20 \mathbf{a b}$ & $75.55 \pm 4.50 \mathbf{a b}$ & $24.45 \pm 3.20 \mathbf{a b}$ & $7.20 \pm 1.80 \mathbf{a b}$ & $1.95 \pm 0.65 \mathbf{c}$ & $159.54 \pm 1.78 \mathbf{a}$ \\
\hline MSY & $96.20 \pm 0.95 \mathbf{b}$ & $3.80 \pm 0.40 \mathbf{a}$ & $75.70 \pm 3.20 \mathbf{a b}$ & $24.30 \pm 2.50 \mathbf{a b}$ & $2.75 \pm 0.20 \mathbf{b c}$ & $2.00 \pm 0.50 \mathbf{b}$ & $158.00 \pm 4.25 \mathbf{a b}$ \\
\hline MCM & $95.80 \pm 1.25 \mathbf{b}$ & $4.20 \pm 0.90 \mathbf{a}$ & $76.88 \pm 2.24 \mathbf{a b}$ & $23.12 \pm 1.75 \mathbf{a b}$ & $5.30 \pm 0.70 \mathbf{b}$ & $2.30 \pm 0.15 \mathbf{b}$ & $139.60 \pm 2.40 \mathrm{~d}$ \\
\hline MCA & $95.40 \pm 0.75 \mathbf{b}$ & $4.60 \pm 0.35 \mathbf{a}$ & $78.73 \pm 3.21 \mathbf{a b}$ & $26.27 \pm 2.40 \mathbf{a}$ & $6.75 \pm 1.40 \mathbf{a b}$ & $2.25 \pm 0.60 \mathbf{b}$ & $148.17 \pm 2.52 \mathbf{c}$ \\
\hline MGK & $95.10 \pm 0.25 \mathbf{b}$ & $4.90 \pm 0.40 \mathbf{a}$ & $71.15 \pm 1.88 \mathbf{b}$ & $28.85 \pm 1.90 \mathrm{a}$ & $4.00 \pm 0.75 \mathbf{b}$ & $5.20 \pm 0.75 \mathbf{a}$ & $155.00 \pm 2.30 \mathbf{b}$ \\
\hline
\end{tabular}

In the same column, the figures followed by the same letter are statistically identical at $5 \%$ threshold of the Newman-Keuls test.

MSJ : "Saint Jean” Market; GMA : Big Market of Abobo ; MR21 : Rue 21 Market; MCA : Market of Cité Abobo ; MDK : Djè Konan Market; MCM : Camp Militaire Market ; MAN : Angré Market; MFA : Forum Adjamé Market; MSY : Selmer Yopougon Market; MGA : Gouro Market of Adjamé ; GMK : Big Market of Koumassi ; NMT : New Market of Treichville

Table 3. Biochemical composition of Cowpea seeds used

\begin{tabular}{llll}
\hline \multicolumn{3}{c}{ Biochemical composition of smooth white Cowpea seeds } \\
\hline & $\begin{array}{l}\text { Carbohydrate } \\
\text { content }(\boldsymbol{\%})\end{array}$ & Protein content $(\boldsymbol{\%})$ & Fat content (\%) \\
\cline { 2 - 4 } Apparently healthy seeds & $79.70 \pm 0.94 \mathbf{a}$ & $22.09 \pm 0.21 \mathbf{a}$ & $2.88 \pm 0.04 \mathbf{b}$ \\
\hline Apparently contaminated seeds & $69.15 \pm 0.24 \mathbf{b}$ & $19.25 \pm 0.35 \mathbf{b}$ & $4.30 \pm 0.04 \mathbf{a}$ \\
\hline
\end{tabular}

In the same column, the figures followed by different letters are statistically different at 5\% threshold of the Newman-Keuls test. 
Assessment of the Effect of Fungal Parasites and Callosobruchus maculatus Fab. on the Physiological and Biochemical Parameters of Cowpea (Vigna unguiculata (L.) Walp.) Seeds in Côte d'Ivoire

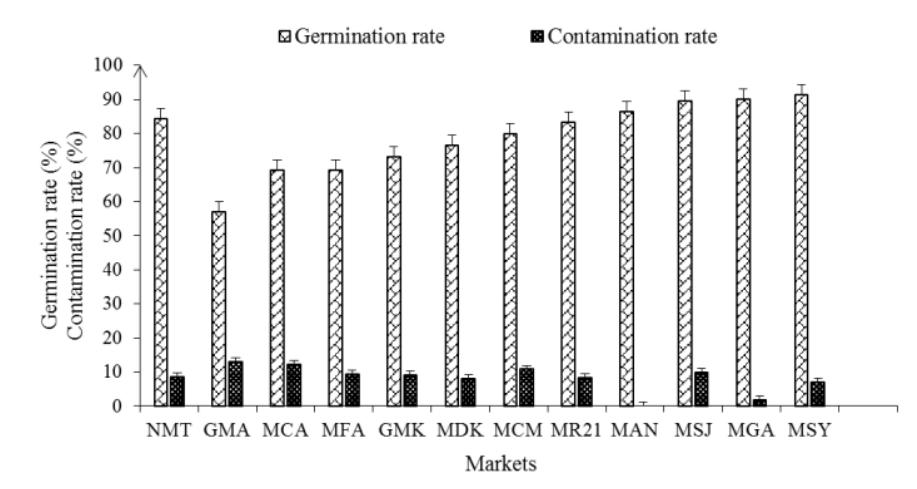

GMA : Big Market of Abobo ; MCA : Market of Cité Abobo ; MFA : Forum Adjamé Market; GMK : Big Market of Koumassi ; MDK : Djè Konan Market; MCM : Camp Militaire Market ; MR21 : Rue 21 Market; MAN : Angré Market; MSJ : "Saint Jean” Market; MGA : Gouro Market of Adjamé ; MSY : Selmer Yopougon Market.

Figure 3. Sanitary and physiological condition of Cowpea seeds in trays

Table 4. Physiological and sanitary characteristics of seeds on PDA media

\begin{tabular}{|c|c|c|c|c|}
\hline \multirow[t]{2}{*}{ Sanitary condition of seeds } & \multirow[t]{2}{*}{$\begin{array}{l}\text { Contamination } \\
\text { rate of fungi }(\%)\end{array}$} & \multicolumn{2}{|c|}{$\begin{array}{l}\text { Contamination rate of fungi } \\
\text { depending on phenotypes }(\%)\end{array}$} & \multirow[t]{2}{*}{$\begin{array}{l}\text { Seed germination } \\
\text { rate }(\%)\end{array}$} \\
\hline & & White (\%) & Black (\%) & \\
\hline Apparently healthy & $6.66 \pm 0.88 \mathbf{a}$ & $2.66 \pm 2.66 \mathbf{a}$ & $4.00 \pm 0.00 \mathbf{a}$ & $100.00 \pm 0.00 \mathbf{a}$ \\
\hline Apparently contaminated & $81.33 \pm 2.33 \mathbf{b}$ & $5.33 \pm 1.33 \mathrm{a}$ & $76.00 \pm 18.03 \mathbf{b}$ & $9.33 \pm 1.42 \mathbf{b}$ \\
\hline
\end{tabular}

In the same column, the figures followed by different letters are statistically different at $5 \%$ threshold of the Newman-Keuls test.

Table 5. Germination and contamination rates of Cowpea seeds on blotting paper

\begin{tabular}{lllll}
\hline & $\begin{array}{l}\text { Rate of non } \\
\text { contaminated } \\
\text { germinated } \\
\text { seeds }\end{array}$ & $\begin{array}{l}\text { Rate of non } \\
\text { contaminated } \\
\text { non germinated } \\
\text { seeds }\end{array}$ & $\begin{array}{l}\text { Rate of } \\
\text { contaminated non- } \\
\text { germinated seeds }\end{array}$ & $\begin{array}{l}\text { Rate of } \\
\text { contaminated } \\
\text { germinated } \\
\text { seeds }\end{array}$ \\
\hline $\begin{array}{l}\text { Appes of Cowpea seeds } \\
\text { (Type 1) }\end{array}$ & $66.67 \pm 288 \mathbf{~ a}$ & $4.17 \pm 0.85 \mathbf{~ a}$ & $19.17 \pm 1.22 \mathbf{b}$ & $10.00 \pm 0.40 \mathbf{a}$ \\
\hline $\begin{array}{l}\text { Apparently } \\
\text { Contaminated (Type 2) }\end{array}$ & $0.00 \pm 0.00 \mathbf{b}$ & $5.00 \pm 1.03 \mathbf{~ a}$ & $95.00 \pm 3.75 \mathbf{~ a}$ & $0.00 \pm 0.00 \mathbf{b}$ \\
\hline
\end{tabular}

In the same column, the figures followed by the same letter are statistically identical at $5 \%$ threshold of the Newman-Keuls test

\section{Characteristics of endogenous fungi associated with seeds}

The isolation of the fungi from the inside of the seeds was made from several explants which showed contaminations on PDA media. Thus, after purification, 2 pure stem fungi were selected. These included a black phenotype fungus and a white phenotype fungus (Table 6). Owing to its high frequency onset, the black phenotype fungus was of particular interest. Thus, its identification has shown that it was Macrophomina phaseoli (Figure $3 \mathrm{~A}$ and B). 
Assessment of the Effect of Fungal Parasites and Callosobruchus maculatus Fab. on the Physiological and Biochemical Parameters of Cowpea (Vigna unguiculata (L.) Walp.) Seeds in Côte d'Ivoire

Table 6. Macroscopic and microscopic characteristics of black and white fungi isolated from smooth white Cowpea seeds.

\begin{tabular}{lll}
\hline Isolated fungi & Macroscopic characteristics & Microscopic characteristics \\
\hline & & - Septate mycelial filaments, \\
& $\begin{array}{l}\text { - Presence of microsclerotia } \\
\text { with average dimensions: } \\
\text { - length: } 58.4116 \mu \mathrm{m}\end{array}$ \\
Black fungus & $\begin{array}{l}\text { - width: } 46.5092 \mu \mathrm{m} \\
\text { filaments }\end{array}$ & - Macrophomina phaseoli \\
\hline \multirow{3}{*}{ White fungus } & $\begin{array}{l}\text { Floccose, whitish mycelial } \\
\text { filaments that turn yellow over } \\
\text { time }\end{array}$ & $\begin{array}{l}\text { - Septate mycelial filaments } \\
\text { - Undetermined }\end{array}$ \\
\hline
\end{tabular}
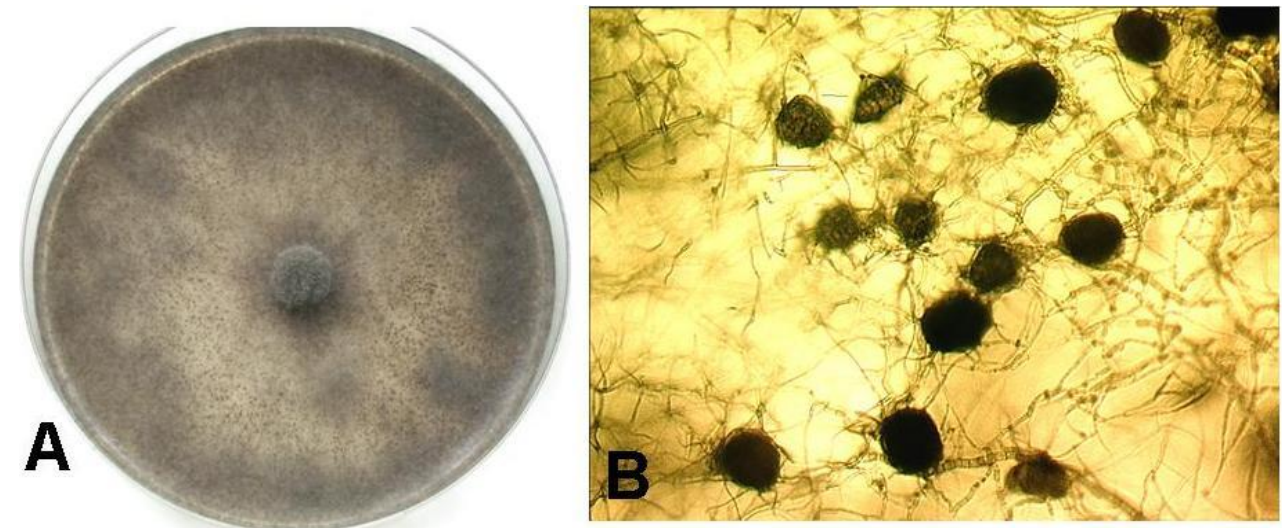

Figure 3. Macroscopic (A) and microscopic (B) appearance of Macrophomina phaseoli.

\section{Characteristics of seed surface fungi on PDA media}

Two fungi were isolated and identified on the seeds of the samples from the different collection markets. These included Penicillium and Aspergillus genera (Figure 4).

The genus Penicillium was characterized by a green color and the genus Aspergillus was characterized a black color on the PDA culture media.

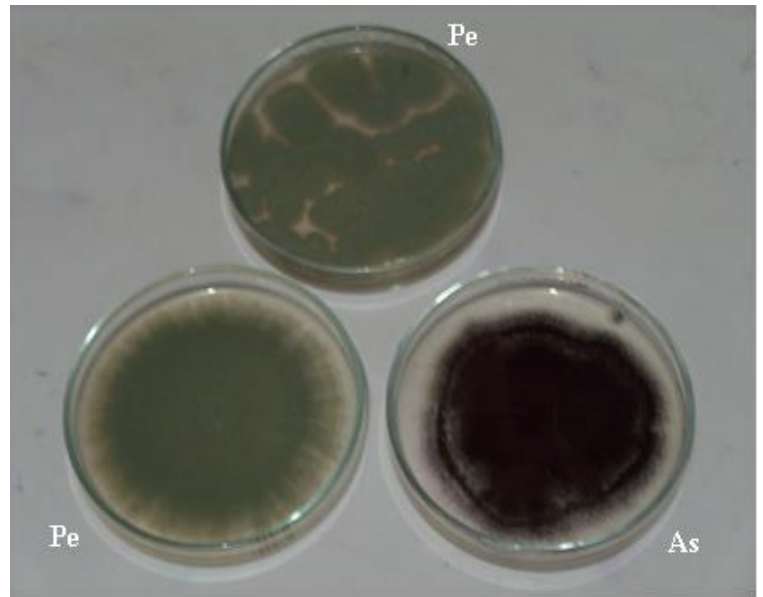

Figure 4. Macroscopic aspects of the different fungal parasites isolated on the surface of the smooth white Cowpea seeds (Pe: Penicillium; As: Aspergillus)
6. Effect of water and biotic factors on seed viability under shelter

\subsection{Seed germination rate under shelter}

Six days after seeding, seed germination ranged from 2.50 to $87.50 \%$ depending on the different treatments (Table VI). The average germination rate was $60.32 \%$. The lowest values (2.50 and $5.00 \%)$ of germination rate were observed in apparently contaminated seeds (T5) and those perforated by $C$. maculatus at the hilum (T6), respectively. The differences observed between these two groups of seed germination rates were significant $(P=0.00)$ at $5 \%$ threshold of the Newman-Keuls test.

\subsection{Plant growth parameters}

Plant growth parameters (plant heights, plant diameter, and number of leaves generated from plants) varied depending on the treatments with significant differences $(\mathrm{P}<0.001)$ (Table 7). Thus, the height of the plants ranged from 0 to $8.05 \mathrm{~cm}$ with a general average of $5.72 \mathrm{~cm}$. The greatest heights were noted with treatments $\mathrm{T} 1(5.91 \mathrm{~cm}), \mathrm{T} 2(7.53$ $\mathrm{cm}), \mathrm{T} 3(8.05 \mathrm{~cm}), \mathrm{T} 4(6.84 \mathrm{~cm}), \mathrm{T} 7(6.07 \mathrm{~cm})$ and T8 $(7.05 \mathrm{~cm})$. The small heights of plants came from the plants of treatments T5 and T6 with heights of $0.24 \mathrm{~cm}$ and $0.00 \mathrm{~cm}$, respectively. 
Assessment of the Effect of Fungal Parasites and Callosobruchus maculatus Fab. on the Physiological and Biochemical Parameters of Cowpea (Vigna unguiculata (L.) Walp.) Seeds in Côte d'Ivoire

Concerning the diameter of the plants, the statistical analyses made it possible to classify the average diameters according to the treatments, in two homogeneous groups (Table 7). The first group, consisting of the highest average diameters, was observed with treatments $\mathrm{T} 1, \mathrm{~T} 2, \mathrm{~T} 3, \mathrm{~T} 4, \mathrm{~T} 7$ and $\mathrm{T} 8$ with values varying between 1.86 and 2.65 . The average values of the shortest diameters were noted with $\mathrm{T} 5(0.08 \mathrm{~mm})$ and $\mathrm{T} 6(0.00 \mathrm{~mm})$ treatments forming thus the second group.
As for the number of leaves generated from the plants it oscillated between 0 and 3.93 leaves for a general average of 2.57 leaves. Treatments T1, T2, T3, T4, T7 and T8 gave the highest number of leaves generated with $2.83 ; 3.68 ; 3.93 ; 3.13 ; 2.93$ and 3.38 leaves, respectively (Table 7). In contrast, treatments T5 (0.10 Leaf) and T6 (0 leaf) generated a very small number of leaves or even nil. The differences noted between the number generated per treatment, were significant $\quad(\mathrm{P} \quad<\quad 0.001)$.

Table 7. Effect of water and biotic factors on seed germination rate and plant growth parameters

\begin{tabular}{lllll}
\hline Treatments & Germination rate $\mathbf{( \% )}$ & Plant height $(\mathbf{C m})$ & $\begin{array}{l}\text { Plant diameter } \\
(\mathbf{m m})\end{array}$ & $\begin{array}{l}\text { Number of leaves } \\
\text { generated }\end{array}$ \\
\hline T1 & & & $1.93 \pm 0.33 \mathbf{a}$ & $2.83 \pm 0.47 \mathbf{a}$ \\
T2 & $67.50 \pm 0.08 \mathbf{a}$ & $5.51 \pm 1.19 \mathbf{a}$ & $2.63 \pm 0.16 \mathbf{a}$ & $3.68 \pm 0.21 \mathbf{a}$ \\
T3 & $85.00 \pm 0.04 \mathbf{a}$ & $7.53 \pm 0.66 \mathbf{a}$ & $2.65 \pm 0.17 \mathbf{a}$ & $3.93 \pm 0.27 \mathbf{a}$ \\
T4 & $87.50 \pm 0.04 \mathbf{a}$ & $8.05 \pm 0.72 \mathbf{a}$ & $2.28 \pm 0.24 \mathbf{a}$ & $3.13 \pm 0.40 \mathbf{a}$ \\
T5 & $75.00 \pm 0.07 \mathbf{a}$ & $6.84 \pm 0.86 \mathbf{a}$ & $0.08 \pm 0.01 \mathbf{b}$ & $0.10 \pm 0.01 \mathbf{b}$ \\
T6 & $2.50 \pm 0.03 \mathbf{b}$ & $0.24 \pm 0.01 \mathbf{b}$ & $0.00 \pm 0.00 \mathbf{b}$ & $0.00 \pm 0.00 \mathbf{b}$ \\
T7 & $5.00 \pm 0.03 \mathbf{b}$ & $0.00 \pm 0.00 \mathbf{b}$ & $1.86 \pm 0.20 \mathbf{a}$ & $2.93 \pm 0.41 \mathbf{a}$ \\
T8 & $77.50 \pm 0.07 \mathbf{a}$ & $6.07 \pm 0.93 \mathbf{a}$ & $2.05 \pm 0.24 \mathbf{a}$ & $3.38 \pm 0.46 \mathbf{a}$ \\
\hline General average & $62.50 \pm 0.05 \mathbf{a}$ & $7.05 \pm 0.96 \mathbf{a}$ & $1.69 \pm 0.17$ & $2.57 \pm 0.28$ \\
Probability & $<0.32 \pm 0.06$ & $5.72 \pm 0.67$ & $<0.001$ & $<0.001$ \\
\hline
\end{tabular}

In the same column, the figures followed by the same letter are statistically identical at $5 \%$ threshold of the Newman-Keuls test

\section{DISCUSSION}

The tests carried out have shown that the purity of Cowpea seeds was different from one market to another. Thus, the high rate of residues of the Big market of Koumassi (4.9\%) might be due to the presence of a large number of crop debris, broom twigs, small pebbles during drying, corpses of insect during storage. Also, the high rate of residues might explain the low rate of pure seeds. The $100 \%$ pure seeds of "Saint Jean" market of Cocody might be in relation with the fact that the sellers in this market perform a careful sorting by removing all residues from the stocks of Cowpea seed in their possession prior to the sale because this would be required by their customers.

The high rate of damaged seeds in the big market of Koumassi $(25.16 \%)$ might be related to unfavorable conditions of drying and storage. In fact, when the seeds are dried by farmers, the material used might break some seeds. Also, poor storage by farmers and sellers might lead to insect access to seeds. Crop storage is traditionally carried out in the form of seeds or pods in lofts where seed weevil damage is significant (Johnson et al., 2006, Kpatinvoh et al., 2016, Mukendi et al., 2016). This is what might justify the condition of some seed lots where insects such as Callosobruchus maculatus cause enormous damage and depreciate the commodity.

The large quantity of intact seeds of the "Saint Jean" market might also be due to the sorting performed by the sellers. The proper conditioning and the respect of hygiene measures by the sellers would avoid the probable attack of insects.

The high rate of apparently contaminated seeds in the big market of Abobo might be caused by the relatively high presence of residues (1.2\%). Indeed, these residues have a harmful action on storage because they may house some fungal and bacterial parasites. They may also ease the development of insects and microorganisms (Cruz et al., 1988, Cissokho et al., 2015).

The 1000-seed weight test revealed that the seeds from the different markets were in the range of 1000 Cowpea seeds defined by Borget (1989). According to this author, the weight of 1000 Cowpea seeds might be between $90 \mathrm{~g}$ and $300 \mathrm{~g}$. Also, the differences in seed weight observed from one market to another could be explained by the fact that the seeds might come from plants grown in different pedo-ecological zones or by differences in seed water 
Assessment of the Effect of Fungal Parasites and Callosobruchus maculatus Fab. on the Physiological and Biochemical Parameters of Cowpea (Vigna unguiculata (L.) Walp.) Seeds in Côte d'Ivoire

content due to the different drying conditions (Moukala et al., 2017). The physiological maturity of the seeds could also explain these differences. Indeed, when a seed has not reached physiological maturity, it does not have enough supply and therefore its weight could be below average.

In terms of health and physiological test in the trays, the low seed germination rate of the big market of Abobo could be explained by the rate of contamination by the fungi responsible for the inhibition of Cowpea seed germination. Our results corroborate those of Cruz et al. (1988) and those of Dedi and Youo (2017). These authors have shown that under certain conditions of temperature and humidity, fungi may develop rapidly and their action might modify qualities such as (the loss of germinability and the alteration of the organoleptic qualities of the seed). The Cocody Angré market seeds that had a nil contamination rate should give the highest germination rate. Now, it has been found that it is relatively average, that is, $86 \%$. This indicates that seed contamination by fungi might not the only cause of inhibition of their germination. Other factors might cause inhibition of germination of certain seeds. These might include inter alia, water impermeability of the seminal envelopes of these seeds that have not been imbibed. The results obtained are similar to those of Como (1982) and Fatarna et al. (2017) who demonstrated that germination consists of 3 successive phases: imbibition, stricto sensu germination and growth.

Concerning the sanitary and physiological test on PDA media, the high frequencies of occurrence of black $(76 \%)$ and white $(5.33 \%)$ phenotype fungi and the low rate of germination $(9.33 \%)$ of apparently contaminated seeds compared to those of apparently healthy ones indicate that these fungi might be responsible for the abnormal coloration (brown, black) of the smooth white Cowpea seeds. These results are in agreement with those of Cruz et al. (1988) who showed that fungi alter the organoleptic characteristics, especially in terms of seed appearance: abnormal pigmentation and discoloration. Also, the results obtained confirm that these isolated fungi are largely responsible for the loss of seed germinability. For apparently healthy seeds, low fungal contamination rates would be justified by the fact that, actually, some of those seeds were contaminated without showing symptoms. But these contaminations might have remained latent until favorable conditions such as moisture/imbibition were achieved for those fungi to emerge. In addition to all these aspects, the sanitary and physiological test on PDA media revealed that the smooth white Cowpea seeds might mainly be contaminated by 2 fungi: one fungus of white phenotype and another of black phenotype. The black phenotype fungus would cause the most damage given its high frequency of occurrence in both types of seeds $(76 \%$ for seeds of apparently contaminated and $4 \%$ for apparently healthy seeds). Its identification revealed that it was Macrophomina phaseoli. Its mycelial filaments were septate and its propagation organs were sclerotia whose dimensions varied between $35.96 \mu \mathrm{m}$ and $84.56 \mu \mathrm{m}$ long and $24.76 \mu \mathrm{m}$ and $77.56 \mu \mathrm{m}$ wide. It is this fungus that might be responsible for the dry rot of smooth white Cowpea seeds.

Regarding the sanitary and physiological test on blotting paper, the high rate of seeds contaminated by fungi that did not germinate $(95 \%)$ and the absence of contaminated seeds that have germinated in type 2 seeds (sterilized apparently contaminated seeds) would confirm the theories that these fungi might be largely involved in abnormal coloring and might prevent germination of those seeds (Hannin et al., 2003, Dedi and Youo, 2017).

Regarding the search for surface fungi of the smooth white Cowpea seeds, 2 fungi were identified. These included: Aspergillus niger and Penicillium sp. These results are in agreement with those of Cruz et al. (1988) who attested that concerning storage, the most represented genera are Aspergillus and Penicillium.

Regarding the test under shelter, the low germination rate of apparently contaminated seeds (T5) at the $6^{\text {th }}$ day after seeding is explained by the fact that the fungi might be largely responsible for the loss of Cowpea seed germinability. Moreover, the low germination rate of the seeds perforated by insects at the hilum (T6) at the $6^{\text {th }}$ day is in agreement with the works of Hyde (1954). Indeed, this author has highlighted the role of the hilum in the dehydration of hard seeds. His works have shown that at the end of maturation, when the integument has become impermeable, water vapor escapes through the hilum that remains open and functions as a valve. Furthermore, in a dry atmosphere, the hilum opens in less than a minute and the seed may lose water (Côme, 1982). In a humid atmosphere, the closure is also quick and prevents rehydration. It appears from those works that the seeds perforated by insects at the hilum might undergo irreversible dehydration and therefore will not be able to germinate. Also, in stocks, insects may cause considerable damage by consuming the albumen and sometimes the seed germ (this is the case in Callosobruchus maculatus, whose larva lives inside the seed and causes irreversible losses.) preventing the seed from germinating. High rates of germination of soaked seeds during 2; 3; and 
Assessment of the Effect of Fungal Parasites and Callosobruchus maculatus Fab. on the Physiological and Biochemical Parameters of Cowpea (Vigna unguiculata (L.) Walp.) Seeds in Côte d'Ivoire

$4 \mathrm{~h}$ (T4, T3 and T2 respectively) indicate on the one hand the important role of imbibition in germination. The water that enters the seed allows the hydrolysis of the supply in simple elements necessary for its germination. On the other hand, these high germination rates indicate that $4 \mathrm{~h}$ would be the ideal soaking time for smooth white Cowpea seeds. However, through their works, Bayard (1991) and Gimeno-Gilles (2009) have shown that after 3 hours of soaking, a period of dehydration is not harmful to the seeds, and has no effect on the speed and subsequent germinability. Thus, the soaked seeds would have enough water within themselves to carry out the germination process. The high germination rates of T7 and T8 seeds (seeds perforated opposite the hilum and on the lateral face by $C$. maculatus), could be explained by the fact that the insects at the origin of the perforations had not deteriorated the germinability of these seeds. They did not consume enough of their albumen and could not destroy their germs. Also, the high germination rate of $\mathrm{T} 1$ intact seeds shows that the smooth white Cowpea seed variety, free from all punctures by insects and from fungal infections, could be content with only the water of the different watering which could be sufficient for a good soaking of the latter so that they can germinate well.

Regarding the other physiological parameters measured (number of leaves, growth in height and diameter of the stems), the rankings of the different average values according to the treatments were practically the same as those of germination. These results are in agreement with the studies of Crosaz (1995) and El Boukhari et al. (2013), which state that among the different physiological mechanisms involved in the germination process, the stricto sensu germination phase is the most important one because it conditions the subsequent growth of the seedlings.

Concerning the extraction and assay of biochemical components, the results indicate that carbohydrate and protein contents would be higher in apparently healthy seeds than in apparently contaminated seeds. This could be explained by the fact that microorganisms (fungi) grow at the expense of the constitutive elements of the seed. They degrade carbohydrates, proteins and certain vitamin elements (Cruz et al., 1988). Unlike the carbohydrate and protein contents, the results showed that the fat content of the apparently contaminated seeds was higher than that of the apparently healthy seeds. This phenomenon could be understood thanks to the studies of Cruz et al. (1988). Thus, according to these authors, the fungi might have significant lipolytic activity which would result in a decrease in the fat contained in the seed and an increase in free fatty acid content. This hydrolysis of lipids into free fatty acid would be accompanied by a synthesis of new free fatty acids. All this will give rise to the nauseating products typical of rancidity which depreciates the commodity. From these studies it appears that the high fat content of apparently contaminated seeds is due to the high production of free fatty acid under the action of fungi.

\section{Conclusion}

The morphological study of smooth white Cowpea seeds has shown that the purity of these seeds depends on the maintenance that the different players bring to the seed stocks. The physiological and sanitary study has revealed that Cowpea seed germination depends essentially on the imbibition of the seeds and their sanitary condition. Seeds perforated by Callosobruchus maculatus at the hilum do not germinate; therefore, they are not of agronomic interest. Moreover, two fungi were isolated on these seeds from the inside. One of white color and the other of black color. These two fungi prevent seed germination. Furthermore, these fungi are responsible for the alteration of the biochemical constituents of the seeds. They depreciate the commodity by degrading carbohydrates, proteins and lipids that constitute the core of their supply. These two fungi are therefore of particular interest, especially Macrophomina phaseoli (black fungus) because of its presence in Cowpea stocks. This fungus has been identified as the most damaging pathogen for smooth white Cowpea seeds. Macrophomina phaseoli and Callosobruchus maculatus therefore constitute real constraints related to Cowpea seed viability during storage and preservation.

\section{References}

1. Ait A.F. Née Kaci, 2017. Activité biologique des principaux constituants de l'huile d'Olive de Kabylie sur Callosobruchus maculatus (Coleoptera : Bruchidae). Thèse de Doctorat de l'Université Mouloud Mammeri de TiziOuzou, Faculté des Sciences Biologiques et des Sciences Agronomiques, $111 \mathrm{p}$.

2. Akédrin T. N., N'guessan K., Aké-Assi E., Kassi N. J., Ake S., 2011. Evaluation des effets comparatifs de 11 Légumineuses herbacées ou subligneuses sur la croissance du maïs, Journal of Applied Biosciences, 37 : 2468-2476.

3. AOAC (Association of Official Analytical Chemists), 2005. Official methods of analysis of the association of official analytical chemists (18th ed.). Current through revision 3, Arlington, VA: The Association, $1140 \mathrm{p}$.

4. Barnett H.L. \& Barry B.H., 1972. Illustrated genera of imperfecti fungi. Third edition. Burgess Publishing Company. Minneapolis, USA, 241 p.

5. Bayard P., 1991. Etude de la germination des semences de 6 espèces herbacées en fonction du régime hydrique, DEA d'agrochimie, Université de Grenoble I. 28 p.

6. Bertrand G. et Thomas P., 1910. Guide pour les manipulations de Chimie Biologie. Dunod et Pinat, Paris, 468 p. 
Assessment of the Effect of Fungal Parasites and Callosobruchus maculatus Fab. on the Physiological and Biochemical Parameters of Cowpea (Vigna unguiculata (L.) Walp.) Seeds in Côte d'Ivoire

7. Bonner F.T., 1974. Seed Testing. In Seed of Wody Plants in the United States, Agriculture Handook $N^{\circ} 450$. For Service, USDA, Washington D.C., 136-152.

8. Borget M., 1989. Le technicien d'Agriculture tropicale : Les légumineuses vivrières tropicales. Collection dirigée par René COSTE, Membre de l'Académie d'Outre-Mer, Ingénieur général d'agronomie: Editions Maisonneuve et Larose 15 rue Victor Cousin 75005 Paris, 23 - 139.

9. Cissokho P.S, Gueye M.T., Sow E.H. \& Diarra K., 2015. Substances inertes et plantes à effet insecticide utilisées dans la lutte contre les insectes ravageurs des céréales et légumineuses au Sénégal et en Afrique de l'Ouest. Int. J. Biol. Chem. Sci., 9(3): 1644-1653.

10. Côme D., 1982. Germination (chapitre 2), dans croissance et développement. Physiologie Végétale II, Mazlik P., Collection Méthode, Herman, Paris, 129 -225.

11. Crosaz Y., 1995. Lutte contre l'érosion des terres noires en montagne méditerranéenne: connaissance du matériel végétal herbacé et quantification de son impact sur l'érosion. Doctorat Sciences de la Vie, Spécialité Ecologie, Université Aix - Marseille III. 244 p.

12. Cruz J.F., Troude F., Griffon D., Hebert J.P., 1988 Conservation des grains en régions chaudes. $2^{\mathrm{e}}$ édition. «Techniques rurales en Afrique ». Paris, France, Ministère de la Coopération et du Développement, 1-26.

13. Dedi K.J. \& Youo D.C., 2017. Évaluation en conditions de conservation des capacités germinatives des semences de deux variétés de riz traditionnelles (Oryza sativa L.) cultivé en Côte d'Ivoire. Journal of Animal \& Plant Sciences, 32 (2): 5146-5155.

14. Djè Y., Bonny B.S. \& Zoro Bi I.A., 2005. [Preliminary observations of variability between some morphotypes of bambara groundnut (Vigna subterranea L., Verdc., Fabaceae) from Côte d'Ivoire]. Biotechnol. Agron. Soc. Environ., 9 (4) : 249-258.

15. Djilé B., Boukar O., Kosma P., Miafo A.-P.T. \& Madi A., 2016. [Agrogenetic diversity of local cultivars of Cowpea (Vigna unguiculata) in the far-north region of Cameroon]. International Journal of Innovation and Applied Studies, 17 (1) : 255-268

16. El Boukhari E.M., Gmira N. \& Brhadda N., 2013. Effet des traitements physiques sur la croissance et le développement des semis de glands de chêne liège (Quercus suber L.) en pépinière forestière au Maroc. Geo-Eco-Trop., 37(2): 177190.

17. Fatarna L., Boutekrabt A., Arabi Y. \& Adda A., 2017. Impact du Cadmium, du Zinc et du Plomb sur la germination des graines d'Atriplex halimus L. (Amaranthaceae). Revue d'Ecologie (Terre et Vie), 72 (1): 61-72.

18. FAO (Organisation des Nations Unies pour l'Alimentation et l'Agriculture), 2017. Division de la statistique. http://www.fao.org/faostat/fr/\#data/QC

19. Gbaguidi A.A., Assogba P., Dansi M., Yedomonhan H. \& Dansi A., 2015. Caractérisation agromorphologique des variétés de niébé cultivées au Bénin. Int. J. Biol. Chem. Sci., 9(2): 1050-1066.

20. Gimeno-Gilles C., 2009. Etude cellulaire et moléculaire de la germination chez Medicago truncatula. Thèse de Doctorat de l'Université D'Angers, 168 p.

21. Guèye M.T., Seck D., Wathelet J.-P. \& Lognay G., 2011. Lutte contre les ravageurs des stocks de céréales et de légumineuses au Sénégal et en Afrique occidentale: synthèse bibliographique., Biotechnol. Agron. Soc. Environ., 15(1), 183-194.

22. Hannin S., Hassikou K., Benkirane R., Ouazzani Touhami A. \& Douira A., 2003. Étude de l'état sanitaire des semences du riz. Actes Inst. Agron. Vet. (Maroc), (2-4): 127-134.

23. Hyde E.O.C., 1954. The function of the hilum in some Papilionaceae in relation to the ripening of the seed and the permeability of the testa, Ann. Bot. N. S., 18: 241-256.
24. IITA (International Institute of Tropical Agriculture), 1982. Annual Report. IITA, Ibadan, Nigeria, 178 p.

25. ISO (International Standardization Organization), 1998 Détermination de la teneur en matière grasse selon la méthode d'extraction par Soxhlet, ISO 659.

26. ISTA (International Seed Testing Association), 1976. International Rules for seed testing. Rules and annexes. Internation seed testing Association, seed sci. And Technol., 4: 3-177.

27. ISTA (International Seed Testing Association), 1999. International Rules for Seed Testing (Vol. 27): Seed Science and Technology, 27: 25-30.

28. ISTA (International Seed Testing Association), 2005. International Rules for Seed Testing, Vol. 2005. doi: http://doi.org/10.15258/istarules.2016.02

29. Johnson F., Seri-Kouassi B., Aboua L.R.N. \& Foua-Bi K., 2006. [Use of powder and total extract of local plants from the genera Ocimum sp. and Mentha sp. as biopesticides in the control of Callosobruchus maculatus FAB.], Agronomie Africaine, 18 (3): 221-233.

30. Kpatinvoh B., Adjou E.S., Dahouenon-Ahoussi E., Konfo T.R.C., Atrevy B.C. \& Sohounhloue D., 2016. Problématique de la conservation du niébé (Vigna unguiculata (L), Walp) en Afrique de l'Ouest : étude d'impact et approche de solution. Journal of Animal \&Plant Sciences, 31(1): 4831-4842.

31. Lalsaga W.J.A., Sawadogo N., Kiebre M. \& Sawadogo M., 2017. Étude du déterminisme génétique de la texture des graines du niébé [Vigna unguiculata (L.) Walp.]. Journal of Applied Biosciences, 114: 11309-11316.

32. Moukala B.J., Mpika J., Yoka J. \& Attiba Y., 2017. Influence de la densité culturale sur la croissance et le rendement de trois cultivars de niébé (Vigna unguiculata (L) Walp.) dans la zone de Kombé en République du Congo. Journal of Applied Biosciences, 118: 11794-11802.

33. Mukendi K.R., Ntanga N.R., Kaseba K.S., Tshiamala N., Kamukenji A. \& Mpoyi K.G., 2016. Dégâts des bruches sur le pouvoir germinatif des graines de quatre variétés de Niébé infesté pendant 60 jours à Ngandajika. Journal of Applied Biosciences, 98: 9323-9329.

34. N'Gbesso F.De P.M., Fondio L., Dibi B.E.K., Djidji H.A. \& Kouamé C.N., 2013. Étude des composantes du rendement de six variétés améliorées de niébé [Vigna unguiculata (L.) Walp], Journal of Applied Biosciences, 63: 4754-4762.

35. Ouali-N'goran S.W.M., Boga J.P., Johnson F., Tano Y. \& Foua-Bi K., 2014. Influence of dietary factors of five varieties of beans sold in Côte d'Ivoire on some biological parameters of Callosobruchus maculatus (Fab.) Coleoptera, Bruchidae. Journal of Animal \& Plant Sciences, 21(1): 32513262.

36. Paul D.K., 1972. A handbook of nursery pratice for Pinus caribaea var. hondurensis and other conifers in West Malaysia. Wkg. Paper $\mathrm{N}^{\circ} 19$, FO: SF / MAL 12, UNDP / FAO, Kuala Lumpur. Malaysia, 139 p.

37. Sérémé P., 1999. La maladie des taches brumes du niébé (Vigna unguiculata (L.) Walp.) au Burkina Faso : Connaissance des agents pathogènes impliqués et développement des méthodes de luttes. Thèse de Doctorat d'Etat. UFR Biosciences, Laboratoire de Physiologie Végétale. Université de Cocody. Abidjan, 18-28.

38. Sérémé P., Kiwallo L. \& Zida E., 1991. Amélioration de la culture du Voandzou (Vigna subterranea (L.) Verdcourt) au Burkina Faso par la lutte contre ses principaux pathogènes. In Influence du climat sur la production des cultures tropicales. Compte rendu du séminaire régional CTA, Ouagadougou, Burkina Faso, 23 - 28 Septembre 1991, 357 - 363.

39. Toudou D.A.K., Atta S., Hamidou F., Inoussa M.M., Bakasso Y. \& Saadou M., 2016. Amélioration du rendement du mil par l'association avec le Niébé en zone Sahélienne. European Scientific Journal, 12 (9) : 382-394. 